\title{
Dynamic Thiol/Disulfide Balance and Ischemia Modified Albumin Levels in Patients with Polycythemia Vera
}

\author{
Polisitemi Veralı Hastalarda Dinamik Thiol/Disulfit Dengesi ve İskemi Modifiye Albumin Düzeyleri
}

\author{
Mahmut Bakır KOYUNCU ${ }^{1}$ \\ (i) 0000-0002-0507-9294 \\ Hakan BASI'R ${ }^{2}$ \\ (D) 0000-0002-8180-5059 \\ Mustafa ILGAN ${ }^{2}$ \\ (1) 0000-0002-6318-3698 \\ Mehmet Ali UÇAR ${ }^{1}$ \\ (1) 0000-0002-6041-7364 \\ Aydan AKDENIZ ${ }^{1}$ \\ (D) 0000-0002-5160-4803 \\ Anıl TOMBAK ${ }^{1}$ \\ (1) 0000-0002-7195-1845 \\ Eyüp Naci TÍFTík ${ }^{1}$ \\ (D) 0000-0002-3178-6005 \\ Salim NEȘELİOGLU ${ }^{3}$ \\ (D) 0000-0002-0974-5717 \\ Özcan EREL ${ }^{3}$ \\ (D) 0000-0002-2996-3236
}

${ }^{1}$ Department of Hematology, Mersin University Faculty of Medicine, Mersin, Turkey

${ }^{2}$ Department of Internal Medicine, Mersin University Faculty of Medicine, Mersin, Turkey

${ }^{3}$ Department of Medical Biochemistry, Yıldırım Beyazit University Faculty of Medicine, Ankara, Turkey

\section{Corresponding Author} Sorumlu Yazar

Mahmut Bakır KOYUNCU

mahmutbakirkoyuncu@gmail.com

Received / Geliş Tarihi : 03.03.2021 Accepted / Kabul Tarihi : 18.06.2021 Available Online /

Çevrimiçi Yayın Tarihi : 30.06.2021

\begin{abstract}
Aim: Polycythemia vera is a chronic myeloproliferative disease characterized by increased red cell mass and JAK2 mutation positivity. Transformation to myelofibrosis and acute leukemia is possible in patients with polycythemia vera. Oxidative stress causes DNA damage and might be a reason for malignant transformation. Thiol molecules can prevent the harmful effects of oxidative stress. Therefore, in this study, we aimed to analyze the state of thiol homeostasis in patients with polycythemia vera.

Material and Methods: Thirty-one patients with polycythemia vera and 80 healthy volunteers were included in this study. Serum samples of the cases were stored until the end of the study. Native thiol, total thiol, disulfide, and ischemia modified albumin levels were determined.

Results: The mean ischemia modified albumin $(1.09 \pm 0.21$ vs $0.67 \pm 0.08 ; \mathrm{p}<0.001$, mean disulfide $(23.5 \pm 6.1$ vs $10.7 \pm 2.6 ; \mathrm{p}<0.001)$, the mean disulfide/native thiol ratio $(5.6 \pm 1.1 \mathrm{vs}$ $3.1 \pm 1.2 ; \mathrm{p}<0.001)$, the mean disulfide/total thiol ratio ( $5.0 \pm 0.9$ vs $2.9 \pm 1.0 ; \mathrm{p}<0.001)$, the mean native thiol $(418.9 \pm 80.6$ vs $371.4 \pm 103.7 ; \mathrm{p}=0.024)$, the mean total thiol $(466.0 \pm 89.8$ vs $393.0 \pm 105.5 ; \mathrm{p}=0.001)$ and the mean disulfide/total thiol ratio $(89.8 \pm 1.8$ vs $94.1 \pm 2.0 ; \mathrm{p}<0.001)$ were found higher in polycythemia vera patients. Ischemia modified albumin levels were also higher in high-risk polycythemia vera patients. Patients on ruxolitinib therapy had higher native thiol, total thiol and disulfide levels, and higher disulfide/native thiol and disulfide/total thiol ratios.

Conclusion: Oxidative stress markers are still high in patients with polycythemia vera who were under treatment. Besides, ruxolitinib may be helpful to decrease oxidative stress in these patients.
\end{abstract}

Keywords: Disulfide; polycythemia vera; oxidative stress; thiol.

ÖZ

Amaç: Polisitemi vera, eritrosit artışı ve JAK2 mutasyonu pozitifliği ile karakterize olan kronik bir miyeloproliferatif hastalıktır. Polisitemi veralı hastalarda miyelofibroz ve akut lösemiye dönüşüm görülebilir. Oksidatif stres, DNA hasarına neden olur ve malign dönüşüme yol açabilir. Tiyol molekülleri, oksidatif stresin zararlı etkilerini önleyebilir. Bu nedenle, bu çalışmada polisitemi veralı hastalarda tiyol homeostazı durumunun analiz edilmesi amaçlandı. Gereç ve Yöntemler: Bu çalışmaya polisitemi veralı 31 hasta ve 80 sağlıklı gönüllü dahil edildi. Vakaların serum örnekleri toplanarak çalışma sonuna kadar saklandı. Doğal tiyol, toplam tiyol, disülfit ve iskemi modifiye albümin seviyeleri belirlendi.

Bulgular: Ortalama iskemi modifiye albümin $(1,09 \pm 0,21$ 'e karşı $0,67 \pm 0,08 ; \mathrm{p}<0,001)$, ortalama disülfit $(23,5 \pm 6,1$ 'e karş1 $10,7 \pm 2,6 ; \mathrm{p}<0,001)$, ortalama disülfit/doğal tiyol oranı $(5,6 \pm 1,1$ 'e karşı $3,1 \pm 1,2 ; \mathrm{p}<0,001)$, ortalama disülfit/toplam tiyol oranı $(5,0 \pm 0,9$ 'a karşı $2,9 \pm 1,0 ; p<0,001)$, ortalama doğal tiyol $(418,9 \pm 80,6$ 'ya karş1 $371,4 \pm 103,7 ; p=0,024)$, ortalama toplam tiyol $(466,0 \pm 89,8393,0 \pm 105,5 ; \mathrm{p}=0,001)$ ve ortalama disülfit/toplam tiyol oranı $\left(89,8 \pm 1,8^{\prime}\right.$ e karş1 $\left.94,1 \pm 2,0 ; p<0,001\right)$ polisitemi vera hastalarında daha yüksek idi. İskemi modifiye albümin düzeyleri ayrıca yüksek riskli polisitemi vera hastalarında daha yüksek idi. Ruksolitinib tedavisi alan hastalar daha yüksek doğal tiyol, toplam tiyol ve disülfit seviyeleri ile daha yüksek disülfit/doğal tiyol ve disülfit/toplam tiyol oranlarına sahipti.

Sonuç: Tedavi altında olan polisitemi veralı hastalarda oksidatif stres belirteçleri hala yüksektir. Ayrıca, ruxolitinib bu hastalarda oksidatif stresi azaltmak için faydalı olabilir.

Anahtar kelimeler: Disülfit; polisitemi vera; oksidatif stress; tiyol. 


\section{INTRODUCTION}

Polycythemia vera (PV) is one of the chronic myeloproliferative neoplasms (MPNs), which presents with increased hemoglobin levels. The clonal proliferation of myeloid cells in bone marrow is the leading cause of this disease. The most important feature that distinguishes PV from other chronic MPNs is increased red blood cell mass. In almost all cases, the JAK2 V617F mutation is present. Due to the increased proliferation of progenitor cells, PV has the potential to transform into myelofibrosis and acute leukemia. Therapeutic phlebotomy, hydroxyurea, interferon, and ruxolitinib are the treatment options in patients with PV. Ruxolitinib is an inhibitor of janus-associated kinases and commonly used in hydroxyurea-resistant or hydroxyurea-intolerant patients. Although the consequences of tyrosine kinase activation caused by JAK2 mutation are well known, the exact mechanism of uncontrolled cell proliferation in PV is still incompletely understood (1).

Oxidative stress is an imbalance between reactive oxygen species (ROS) and antioxidants (2). ROS contributes to DNA damage with toxic substances. There are several mechanisms to protect the organism against the unfavorable effects of ROS. Thiol compounds that contain sulfhydryl groups are among these mechanisms. ROS oxidizes the thiol groups and forms reversible disulfide bonds. Antioxidants degrade the disulfide bonds to thiol groups again, and thus thiol/disulfide homeostasis is maintained $(3,4)$. This homeostasis has an essential role in regulating apoptotic pathways, signal transmission, and transcription. Abnormal dynamic thiol/disulfide hemostasis has been shown in several diseases such as solid malignancies, cardiovascular diseases, rheumatoid arthritis, myelodysplastic syndrome, Alzheimer's disease, and diabetes mellitus (5-10).

In ischemia conditions, free oxygen radicals modify the $\mathrm{N}$-terminal of the albumin, and this new form is referred to as ischemia modified albumin (IMA) (11). Several studies suggested that IMA could be used as a marker for oxidative stress in diseases such as acute coronary syndrome, diabetes mellitus, preeclampsia, and acute pancreatitis (12-14).

We could not find any study about thiol compounds and IMA levels in patients with PV. Therefore, we aimed to analyze the thiol/disulfide homeostasis and IMA levels in patients with PV.

\section{MATERIAL AND METHODS}

Thirty-one patients who were being followed at Mersin University, Department of Hematology, and 80 healthy volunteers, were included in this study. The inclusion criteria for patient group were as follows: being over 18 years old, being diagnosed with PV and signing the informed consent form. PV diagnosis was confirmed by bone marrow samples, JAK2 V617F and JAK2 exon12 mutation status according to the 2016 World Health Organization diagnostic criteria. Patients who did not sign the informed consent form, and those who are currently using antioxidant drugs (statin, etc.) were excluded from the study. Between November 2020 and January 2021, blood samples were collected from patients who came to our clinic for control.

Management of patients with PV is based on a riskadopted approach. Patients who are $\leq 60$ years old with no history of thrombosis are classified as low risk; all others are considered high-risk (15). Thiol, disulfide, and IMA changes according to risk stratification were evaluated. In addition, patients were grouped according to the four different types of treatment (therapeutic phlebotomy, hydroxyurea, ruxolitinib, and pegylated interferon) they used.

This study was conducted in accordance with the Declaration of Helsinki. It was approved by the Mersin University Ethics Committee (decision date: 14.10.2020 no: 2020/708). Written informed consent of all patients and controls were obtained.

\section{Biochemical Evaluation}

Blood samples were taken following overnight fasting. The blood samples were centrifuged at $4000 \mathrm{rpm}$ for 10 minutes, and the serum samples were separated. Serum samples were stored at $-80^{\circ} \mathrm{C}$ until all blood samples were collected.

\section{IMA Measurement}

IMA measurements were made by the ELISA method, and the results were given in $\mathrm{ng} / \mathrm{mL}$.

\section{Dynamic Thiol/Disulfide Homeostasis}

The thiol/disulfide homeostasis tests were studied with a new method previously described by Erel et al. (16). To mention briefly, reducible disulfide bonds were reduced to form free functional thiol groups using sodium borohydride. Formaldehyde was used to remove residual sodium borohydride and 5,5'-disulfanediylbis (2nitrobenzoic acid) products. Later, both reduced and native natural thiol groups were determined. The amount of dynamic disulfide was acquired by dividing the variance between total and natural thiol. Disulfide/total thiol, disulfide/native thiol, and native thiol/total thiol levels were calculated as percentages.

Disulfide levels, disulfide/native thiol, and disulfide/total thiol ratios, native thiol/total thiol levels were compared in PV patients and the control group. The clinical relationship between disulfide, disulfide/native thiol, and disulfide/total thiol levels and PV risk stratification was investigated. Also, levels of thiol compounds and IMA levels were evaluated according to treatment modality in PV patients.

\section{Statistical Analysis}

Shapiro-Wilk test was used to control the normal distribution of data. Mean and standard deviation were given for parameters suitable for normal distribution, median and interquartile range values were given for the data that were not normally distributed. Number and percentage values were presented as descriptive statistics for variables in a categorical structure. The Student's t-test was used to compare two groups with a normal distribution. For groups that were not normally distributed, Mann-Whitney U test was used. The Pearson correlation coefficient was used to compare the relationships between variables. In assessing the data, SPSS v.22 statistical package program has been used. Statistical significance was taken as $\mathrm{p}<0.05$.

\section{RESULTS}

Some demographic and clinical characteristics of the patients were presented in Table 1 . The mean IMA $(1.09 \pm 0.21$ vs $0.67 \pm 0.08 ; \mathrm{p}<0.001$, mean disulfide (23.5 \pm 6.1 vs $10.7 \pm 2.6 ; \mathrm{p}, 0.001$ ), the mean disulfide/native 
thiol ratio $(5.6 \pm 1.1$ vs $3.1 \pm 1.2 ; \mathrm{p}<0.001)$, the mean disulfide/total thiol ratio $(5.0 \pm 0.9$ vs $2.9 \pm 1.0 ; \mathrm{p}<0.001)$, the mean native thiol $(418.9 \pm 80.6$ vs $371.4 \pm 103.7$; $\mathrm{p}=0.024)$, the mean total thiol $(466.0 \pm 89.8$ vs $393.0 \pm 105.5 ; \mathrm{p}=0.001)$ and the mean disulfide/total thiol ratio $(89.8 \pm 1.8$ vs $94.1 \pm 2.0 ; \mathrm{p}<0.001)$ were found higher in PV patients. The mean WBC, neutrophile, and platelet counts were higher, while the mean lymphocyte count and hemoglobin level were lower in the PV group (Table 2).

Three $(9.7 \%)$ of the patients were on phlebotomy treatment when needed, $22(70.9 \%)$ of the patients were under

Table 1. Demographic and clinical characteristics of the patients

\begin{tabular}{lcc}
\hline & PV $(\mathbf{n}=\mathbf{3 1})$ & Control $(\mathbf{n}=\mathbf{8 0})$ \\
\hline Age (year), mean \pm SD & $60.2 \pm 14.7$ & $54.5 \pm 17.4$ \\
Gender, n (\%) & $12(38.7 \%)$ & $23(28.8 \%)$ \\
$\quad$ Female & $19(61.3 \%)$ & $57(71.2 \%)$ \\
$\quad$ Male & & \\
Current Treatment, n (\%) & $3(9.7 \%)$ & \\
$\quad$ Therapeutic Phlebotomy & $22(70.9 \%)$ & - \\
$\quad$ Hydroxyurea & $5(16.1 \%)$ & \\
$\quad$ Ruxolitinib & $1(3.2 \%)$ & \\
$\quad$ Pegylated-Interferon & \\
\hline PV: Polycythemia vera, SD: standard deviation
\end{tabular}

Table 2. Laboratory parameters of the patients

\begin{tabular}{lccc}
\hline & PV $(\mathbf{n}=\mathbf{3 1})$ & Control $(\mathbf{n}=\mathbf{8 0})$ & $\mathbf{p}$ \\
\hline IMA $(\mathrm{ng} / \mathrm{mL})$ & $1.09 \pm 0.21$ & $0.67 \pm 0.08$ & $<\mathbf{0 . 0 0 1}$ \\
Native thiol $(\mathrm{mmol} / \mathrm{L})$ & $418.9 \pm 80.6$ & $371.4 \pm 103.7$ & $\mathbf{0 . 0 2 4}$ \\
Total thiol (mmol/L) & $466.0 \pm 89.8$ & $393.0 \pm 105.5$ & $\mathbf{0 . 0 0 1}$ \\
Disulfide (mmol/L) & $23.5 \pm 6.1$ & $10.7 \pm 2.6$ & $<\mathbf{0 . 0 0 1}$ \\
SH/TT (\%) & $89.8 \pm 1.8$ & $94.1 \pm 2.0$ & $<\mathbf{0 . 0 0 1}$ \\
SS/TT (\%) & $5.0 \pm 0.9$ & $2.9 \pm 1.0$ & $<\mathbf{0 . 0 0 1}$ \\
SS/SH (\%) & $5.6 \pm 1.1$ & $3.1 \pm 1.2$ & $<\mathbf{0 . 0 0 1}$
\end{tabular}

PV: polycythemia vera, IMA: ischemia modified albumin, SH/TT: native thiol/total thiol, SS/TT: disulfide/total thiol, SS/SH: disulfide/native thiol hydroxyurea treatment, $5(16.1 \%)$ of the patients had started on ruxolitinib, and $1(3.2 \%)$ of the patients was under pegylated interferon therapy (Table 1$)$.

Patients who were on ruxolitinib had higher native thiol, total thiol, disulfide, disulfide/native thiol, disulfide/total thiol, IMA, and lower native thiol/total thiol (Figure 1). The difference in terms of IMA levels was statistically significant $(\mathrm{p}=0.009)$.

Twenty $(38.7 \%)$ of the patients had low-risk disease, while $19(61.3 \%)$ had high-risk disease. Mean thiol parameters, according to PV risk stratification, were revealed in Table 3. There was no statistically significant difference between low-risk and high-risk patients in terms of native thiol, total thiol, disulfide, disulfide/native thiol, disulfide/total thiol, and native thiol/total thiol. On the other hand, mean IMA levels $(0.99 \pm 0.16$ vs. $1.15 \pm 0.21$; $\mathrm{p}=0.045$ ) were higher in high-risk patients.

The mean spleen size of the patients was $135.2 \pm 27.3 \mathrm{~mm}$. Spleen size was negatively correlated with native thiol $(\mathrm{r}=0.396, \mathrm{p}=0.027)$ and total thiol levels $(\mathrm{r}=0.399$, $\mathrm{p}=0.026)$. Oher thiol parameters and IMA levels were not significantly associated with spleen size.

Table 3. Laboratory parameters according to risk stratification in PV patients

\begin{tabular}{lccc}
\hline & $\begin{array}{c}\text { Low risk } \\
(\mathbf{n = 1 2})\end{array}$ & $\begin{array}{c}\text { High Risk } \\
(\mathbf{n = 1 9 )}\end{array}$ & $\mathbf{p}$ \\
\hline IMA (ng/mL) & $0.99 \pm 0.16$ & $1.15 \pm 0.21$ & $\mathbf{0 . 0 4 5}$ \\
Native thiol (mmol/L) & $435.45 \pm 75.4$ & $408.46 \pm 84.1$ & 0.373 \\
Total thiol (mmol/L) & $481.59 \pm 83.3$ & $456.31 \pm 94.5$ & 0.455 \\
Disulfide (mmol/L) & $23.06 \pm 5.27$ & $23.92 \pm 6.75$ & 0.712 \\
SH/TT (\%) & $90.43 \pm 2.40$ & $89.52 \pm 2.08$ & 0.194 \\
SS/TT (\%) & $4.78 \pm 0.70$ & $5.23 \pm 1.04$ & 0.194 \\
SS/SH (\%) & $5.30 \pm 0.85$ & $5.88 \pm 1.29$ & 0.181 \\
\hline PV: polycythemia vera, IMA: ischemia modified albumin, SH/TT: native thiol/total
\end{tabular}

PV: polycythemia vera, IMA: ischemia modified albumin, SH/TT: native thiol/total thiol, SS/TT: disulfide/total thiol, SS/SH: disulfide/native thiol
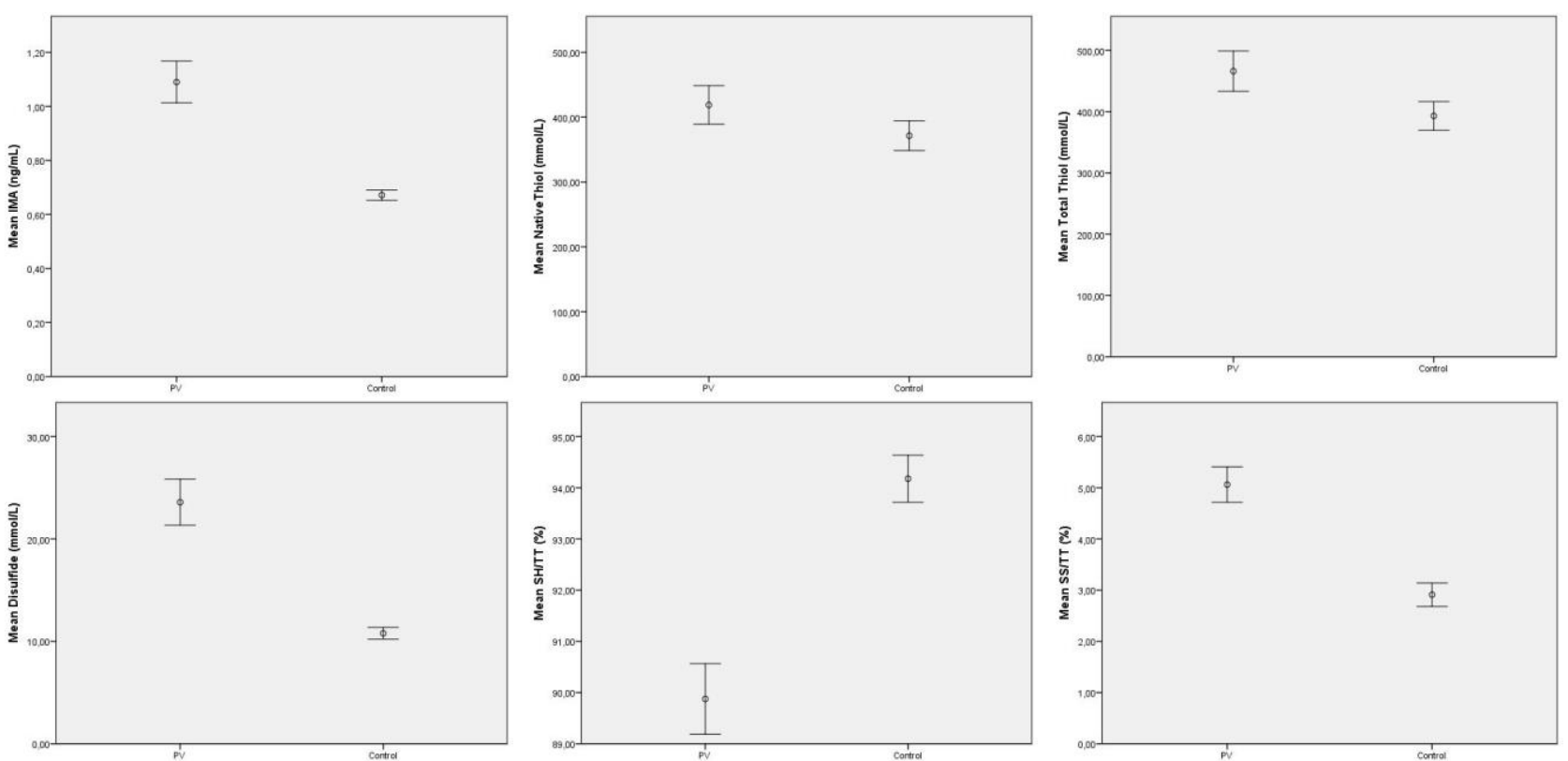

Figure 1. Error bars showing differences between patients with polycythemia vera and control group in terms of laboratory parameters, IMA: ischemia modified albumin, SH/TT: native thiol/total thiol, SS/TT: disulfide/total thiol 


\section{DISCUSSION}

The results of this study have shown that IMA, native and total thiol, disulfide levels, disulfide/native thiol, and disulfide/total thiol ratios are elevated in PV patients. These results indicate that thiol/disulfide hemostasis shifts towards proliferation.

Several studies report that oxidative stress could play a role in myeloproliferative neoplasms' etiopathogenesis (17-20). However, we could not find any studies about the dynamic thiol/disulfide homeostasis in PV patients. We believe that this is the first study about this issue.

Oxidative stress and some genetic alterations in myeloid progenitor cells are related to myeloproliferative diseases. Some previous studies showed that oxidative stress markers other than thiol markers increase in patients with polycythemia vera $(21,22)$. Cancer cells try to elevate their antioxidant capacities to adapt to oxidative conditions (23). The sulfhydryl groups of thiol compounds form a resistance mechanism against free oxygen radicals. The increase of free oxygen radicals due to the decrease in thiol levels causes obstacles in cellular pathways $(24,25)$.

Erel et al. (16) showed that plasma disulfide levels are higher in patients with inflammatory and malignant diseases. In our study, it was observed that plasma disulfide levels were higher in the patient group. It was also found that native and total thiol levels were significantly lower in the patient group. Previous studies showed that native and total thiol levels are markedly higher in malignant hematological diseases such as myelodysplastic syndrome and multiple myeloma $(4,26)$. From this point of view, it is seen that the results in our study are similar to the literature.

Ruxolitinib is an advanced treatment in patients with PV who are unresponsive to first-line therapies such as Therapeutic phlebotomy, hydroxyurea, and interferon. Although patients who were on ruxolitinib are resistant to other treatments, they had better oxidative stress results. This situation may prove that ruxolutinib is also effective on oxidative stress. Besides, higher IMA levels in these patients may be related to the fact that they had a worse prognosis than others. Since only five patients on ruxolitinib were included in this study, studies involving more patients are needed.

One of the most significant limitations of our study was that patients were not newly diagnosed. All of them had under a treatment modality. Moreover, the number of patients was small. New prospective studies should be designed to show thiol changes before and after treatment.

\section{CONCLUSION}

This study is critical because it supports that oxidative stress is still worse in patients with PV, even if they are under treatment. Additionally, ruxolitinib may be essential to decrease oxidative stress in these patients. With multicenter prospective and randomized controlled studies in the future, we believe that the importance of thiol/disulfide hemostasis will be better understood.

Ethics Committee Approval: The study was approved by the Clinical Research Ethics Committee of Mersin University (14.10.2020, 708).
Conflict of Interest: None declared by the authors.

Financial Disclosure: None declared by the authors.

Acknowledgements: None declared by the authors.

Author Contributions: Idea/Concept: MBK, MAU, ÖE; Design: MBK, AA, AT; Data Collection/Processing: MBK, HB, MI; Analysis/Interpretation: AT, SN, ÖE; Literature Review: MBK, AA, AT, ENT; Drafting/Writing: MBK, HB, MI, MAU, AA, AT; Critical Review: MAU, AA, AT, ENT, SN, ÖE.

\section{REFERENCES}

1. Büyükaşik $Y$, Alİ R, Ar C, Turgut $M$, Yavuz S, Saydam G. Polycythemia vera: diagnosis, clinical course, and current management. Turk J Med Sci. 2018;48(4):698-710.

2. Uttara B, Singh AV, Zamboni P, Mahajan RT. Oxidative stress and neurodegenerative diseases: a review of upstream and downstream antioxidant therapeutic options. Curr Neuropharmacol. 2009;7(1):65-74.

3. Winterbourn CC, Hampton MB. Thiol chemistry and specificity in redox signaling. Free Radic Biol Med. 2008;45(5):549-61.

4. Ucar MA, Tombak A, Dagdas S, Akdeniz A, Ceran F, Neselioglu $S$, et al. Is dynamic thiol/disulfide homeostasis associated with the prognosis of myelodysplastic syndrome? J Med Biochem. 2020;39(3):336-45.

5. Kundi H, Ates I, Kiziltunc E, Cetin M, Cicekcioglu H, Neselioglu S, et al. A novel oxidative stress marker in acute myocardial infarction; thiol/disulphide homeostasis. Am J Emerg Med. 2015;33(11):1567-71.

6. Demirseren DD, Cicek C, Alisik M, Demirseren ME, Aktaş A, Erel O. Dynamic thiol/disulphide homeostasis in patients with basal cell carcinoma. Cutan Ocul Toxicol. 2017;36(3):278-82.

7. Eryilmaz MA, Kozanhan B, Solak I, Çetinkaya ÇD, Neselioglu S, Erel Ö. Thiol-disulfide homeostasis in breast cancer patients. J Cancer Res Ther. 2019;15(5):1062-6.

8. Dirican N, Dirican A, Sen O, Aynali A, Atalay S, Bircan HA, et al. Thiol/disulfide homeostasis: A prognostic biomarker for patients with advanced non-small cell lung cancer? Redox Rep. 2016;21(5):197-203.

9. Gündüztepe Y, Bukan N, Zorlu E, Karaman Y, Andaç Topkan T, Gurbuz N, et al. The evaluation of thioldisulfite balance, ischemia albumin modification and seruloplazmine as a new oxidative stress in mild cognitive impairment and early stage alzheimer's disease patients. J Clin Neurosci. 2020;75:188-94.

10. Gulpamuk B, Tekin K, Sonmez K, Inanc M, Neselioglu S, Erel O, et al. The significance of thiol/disulfide homeostasis and ischemia-modified albumin levels to assess the oxidative stress in patients with different stages of diabetes mellitus. Scand J Clin Lab Invest. 2018;78(1-2):136-42.

11. Bar-Or D, Lau E, Winkler JV. A novel assay for cobaltalbumin binding and its potential as a marker for myocardial ischemia-a preliminary report. J Emerg Med. 2000;19(4):311-5. 
12. Karaşin SS, Çift T. The role of ischemia-modified albumin as a biomarker in preeclampsia. Rev Bras Ginecol Obstet. 2020;42(3):133-9.

13. Oran I, Oran B. Ischemia-modified albumin as a marker of acute coronary syndrome: the case for revising the concept of "N-terminal modification" to "Fatty Acid Occupation" of albumin. Dis Markers. 2017;2017:5692583.

14. Sahin A, Turkoglu S, Tunc N, Duzenci D, Solmaz OA, Bahcecioglu IH, et al. Is ischemia-modified albumin a reliable tool for the assessment of acute pancreatitis? Ther Clin Risk Manag. 2018;14:627-35.

15. Finazzi G, Barbui T. How I treat patients with polycythemia vera. Blood. 2007;109(12):5104-11.

16. Erel O, Neselioglu S. A novel and automated assay for thiol/disulphide homeostasis. Clin Biochem. 2014;47(18):326-32.

17. Pascu VÎnturiȘ EG, GĂman AM. Assessment of oxidative stress in patients with chronic myeloid leukemia depending on associated comorbidities. Curr Health Sci J. 2020;46(1):23-30.

18. Rossi C, Zini R, Rontauroli S, Ruberti S, Prudente Z, Barbieri G, et al. Role of TGF- $\beta 1 / \mathrm{miR}-382-5 \mathrm{p} / \mathrm{SOD} 2$ axis in the induction of oxidative stress in CD34+ cells from primary myelofibrosis. Mol Oncol. 2018;12(12):2102-23.

19. Bjørn ME, Hasselbalch HC. The role of reactive oxygen species in myelofibrosis and related neoplasms. Mediators Inflamm. 2015;2015:648090.
20. Allegra A, Pioggia G, Tonacci A, Casciaro M, Musolino C, Gangemi S. Synergic crosstalk between inflammation, oxidative stress, and genomic alterations in BCR-ABL-negative myeloproliferative neoplasm. Antioxidants (Basel). 2020;9(11):1037.

21. Musolino C, Allegra A, Saija A, Alonci A, Russo S, Spatari G, et al. Changes in advanced oxidation protein products, advanced glycation end products, and snitrosylated proteins, in patients affected by polycythemia vera and essential thrombocythemia. Clin Biochem. 2012;45(16-17):1439-43.

22. Durmus A, Mentese A, Yilmaz M, Sumer A, Akalin I, Topal C, et al. The thrombotic events in polycythemia vera patients may be related to increased oxidative stress. Med Princ Pract. 2014;23(3):253-8.

23. Pilo F, Angelucci E. A storm in the niche: Iron, oxidative stress and haemopoiesis. Blood Rev. 2018;32(1):29-35.

24. Winterbourn CC. Are free radicals involved in thiolbased redox signaling? Free Radic Biol Med. 2015;80:164-70.

25. Poole LB. The basics of thiols and cysteines in redox biology and chemistry. Free Radic Biol Med. 2015;80:148-57.

26. Ellidag HY, Aydin O, Eren E, Yilmaz N, Ergin M. Decreased HDL-dependent paraoxonase and arylesterase enzyme activity may indicate a worse prognosis in multiple myeloma. Asian Pac J Cancer Prev. 2014;15(22):9847-51. 